\title{
CONSTRUCTING IDENTITIES IN EARLY IRON AGE THESSALY: THE CASE OF THE HALOS TUMULI
}

\begin{abstract}
Summary. This paper examines the Early Iron Age tumulus-cemetery of Halos in south-eastern Thessaly, with its unique cremation pyre-cairn combination. As there are no parallels for such combination of burial practices either in Thessaly or in any other area of the Greek world, it has usually been suggested that the tumuli were erected by people foreign to Thessaly, most probably of a northern origin. This paper presents evidence suggesting a local custom closely related to the desire to create a new identity.
\end{abstract}

\section{INTRODUCTION}

Towards the end of the Protogeometric period ${ }^{1}$ (c.900 BC), the people who lived in the area that was later known as Halos started cremating their dead, covering the cremation pyres with cairns of stones and then erecting a tumulus over them (Figure 1).

Although tumuli have a very long history in the Greek world, with the earlier examples dating to the Early Helladic period (Pelon 1976; Muller 1989), in Thessaly they were never popular and during the Mycenaean period the very few examples come mainly from the periphery of the region, like the Late Helladic IIIC tumulus at Hexalophos (Theocharis 1968, 289-95). During the Early Iron Age tumuli occur more often in the neighbouring regions of Macedonia, Epirus and Phthiotis, but are still not particularly common in Thessaly. ${ }^{2}$

As far as cremation is concerned, it is not only the people of Halos who adopt it during this period but most of the Thessalians as well. ${ }^{3}$ It is only at Halos, however, that the cremation pyres are covered by cairns of stones.

In Thessaly, besides Halos, EIA tumuli have also been found at the sites of Agioi Theodoroi and Chyretiai. At Agioi Theodoroi several mounds have been reported, although only one of them has been excavated. The latter, which had a diameter of $27 \mathrm{~m}$ and a height of 5 $\mathrm{m}$, concealed a tholos tomb (diameter $5.50 \mathrm{~m}$, height $4.10 \mathrm{~m}$ ) dated to the PG-G periods. ${ }^{4}$ At Chyretiai, Arvanitopoulos $(1914,168)$ reported the presence of a tumulus which had been erected over four or five tholos tombs, but without giving any further information. Furthermore,

\footnotetext{
1 Refer to list of abbreviations at end for acronyms used in the following discussion.

2 Macedonia: Vergina (Andronikos 1969), Dion (Pantermalis 1989; 1997) and Chauchitsa (Casson 1919-21; 1923-25). Epirus: several tumuli at the site of Pogoni and its adjacent areas (Andreou and Andreou 1999 for the latest review). Phthiotis: the Submycenaean tumulus cemetery of Marmara (Dakoronia 1987).

3 For example, the LPG/SPG I cremations found in tholos tombs at Argyropouli, Dranista, Nea Anchialos and Kapakli (Georganas 2000, 51).

4 A. Delt 45 (1990), 204-5. Henceforth, all A. Delt refer to Chronika.
} 


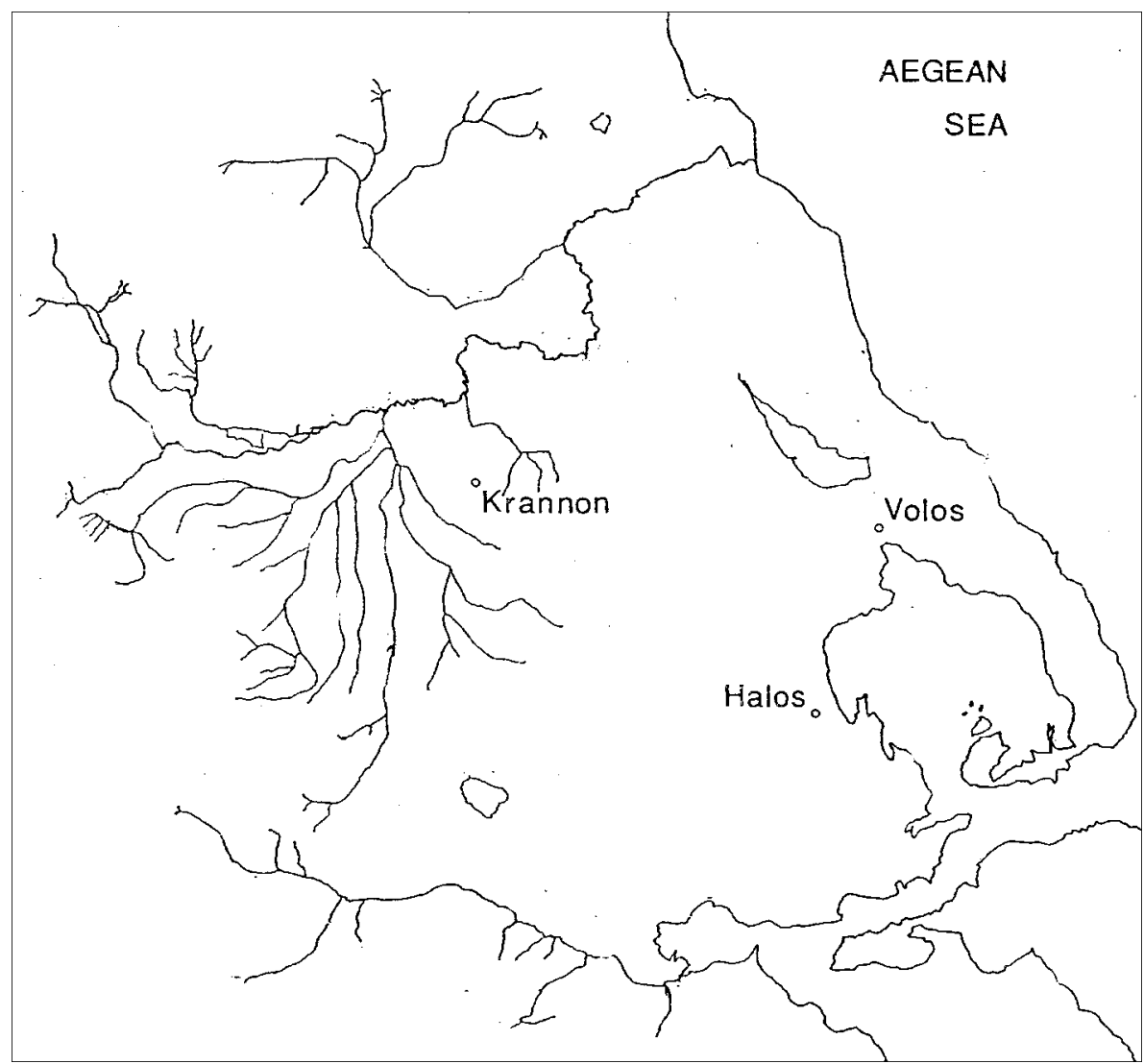

Figure 1

Map of Thessaly.

Kalligas $(1992,300)$ has suggested the presence of tumuli at the sites of Velestino (Temple of Enodia/Thaulios Zeus) and Volos. There are, however, no archaeological data to back up this assumption.

The following analysis of the Halos tumuli clearly shows that they were very different both from other Thessalian tumuli and from those known in other Greek regions.

\section{THE CEMETERY OF HALOS}

The tumulus-cemetery covers an area of over $1.5 \mathrm{~km}^{2}$ and it is located at the site of Voulokalyva, $5 \mathrm{~km}$ east of the modern village of Platanos and west of the ancient city of Halos (Figure 2). Thirty-seven tumuli have been reported so far, although only five of them are fully excavated. Moreover, there is evidence for the presence of four more tumuli in the vicinity. ${ }^{5}$ The necropolis, which was in use from the LPG to the Archaic period, was most probably associated with the nearby EIA settlement at the site of Kephalosis (Efstathiou et al. 1990, 35).

5 Another tumulus has been very recently excavated by the 13th Ephorate of Prehistoric and Classical Antiquities. 


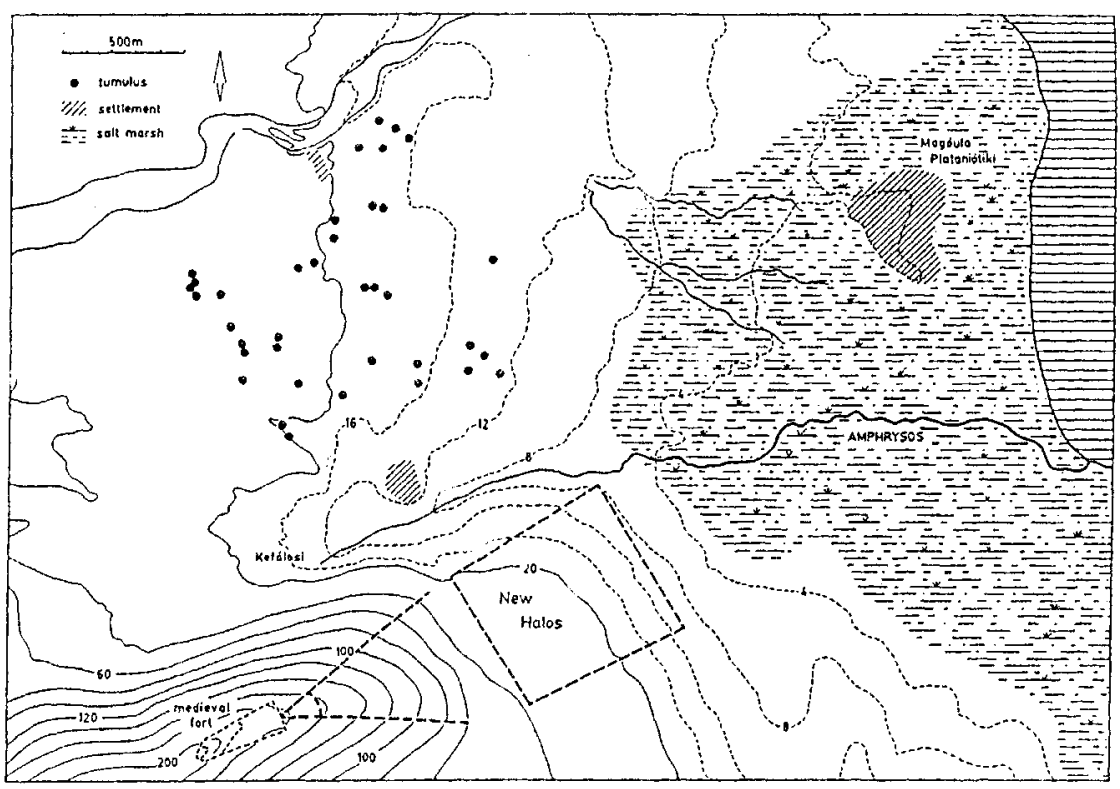

Figure 2

The Halos Tumulus-cemetery in the Voulokalyva Area (after Efstathiou et al. 1990, 43, fig. 5).

The first tumulus (Tumulus E) was excavated in 1899 by the local archaeological society 'Othrys' (Giannopoulos 1899, 31-2). It stood 4.5-5 m above ground and was made of large river-worn stones mixed with earth. At a depth of $2 \mathrm{~m}$ bones of sacrificed animals were found, while at a depth of $2.5 \mathrm{~m}$ the cremation pyres came to light. Further down at a depth of 4.5-5 m, fragments of pottery, lumps of burnt bronze and two iron spearheads were found. The excavator, who dates the tumulus to the eighth century BC, describes it as a polyandreion, a warrior mass grave. This explanation is most probably incorrect after taking into consideration the evidence from the other tumuli as well. The fact that offerings were found below the level of the pyres, although odd, could probably be explained as the result of a later reuse of the tumulus.

In 1912, Wace and Thompson (1911-12, 1-29) excavated another tumulus (Tumulus A). It measured 18 to $20 \mathrm{~m}$ in diameter and stood over $2 \mathrm{~m}$ above ground. It was made of large river-worn stones mixed with earth. At a depth of about a metre, 16 pyres were found. Each was covered by a heap of large stones, rough slabs and smaller river-worn stones. Most of these cairns were about $0.60 \mathrm{~m}$ high and $2.40 \mathrm{~m}$ in diameter. Directly below was a burnt deposit 0.10 $0.20 \mathrm{~m}$ thick which contained wood ash, fragments of burnt human bones, pottery, iron weapons, bronze jewellery and other gear. The bodies must have been burnt in situ, as the soil had been baked hard. The shape of each pyre was irregular and there was no sign of any order in the position of one pyre relative to another. From the arrangement of the metal offerings in the pyres it has been concluded that ten cremations were of men and six were of women. The burials seem to extend over two generations, spanning the early and mid-eighth century.

The other three excavated tumuli (Alpha, Beta and Gamma) are all located in the Despotopoulos field and were excavated by the 13th Ephorate of Prehistoric and Classical 
Antiquities. Tumulus Alpha ${ }^{6}$ measured 21.50 by $29 \mathrm{~m}$ and stood $2.87 \mathrm{~m}$ above the present level of the plain. It was made of rough and river-worn stones mixed with earth. The tumulus was erected over a small circular tomb, a peribolos, ${ }^{7}$ and 52 pyres. The peribolos had a diameter of $1.80 \mathrm{~m}$ and a preserved height of $0.99 \mathrm{~m}$. A cremation pit (diameter $0.90 \mathrm{~m}$, depth $0.35 \mathrm{~m}$ ), associated with very burnt earth, ashes and red burnt clay, was cut in its floor. The enclosure did not have an entrance. All the pyres, which were located in front of the peribolos, shared similar dimensions (0.60-0.70 m deep) and were either circular, ellipsoidal or horseshoeshaped. Their walls were made of stones similar to those used for the tumulus. Some of the pyre pits had an opening, functioning as an entrance. The pyres were full of burnt fill, charred wood, burnt human bones and various offerings such as pottery, iron weapons, bronze jewellery and vessels. It should be noted that between the pyres several standing slabs were found, probably serving as funeral stelai.

Tumulus Beta $^{8}$ measured 20 by $19 \mathrm{~m}$ and stood over $3.10 \mathrm{~m}$ above the ground level. Like Tumulus Alpha, it was made of rough limestone and river-worn stones. The tumulus concealed a small peribolos, 43 pyres, two pithos burials and 25 graves (both cists and pits, all belonging to children). The peribolos, located in the centre of the tumulus, had a diameter of $2.35 \mathrm{~m}$ and a preserved height of $0.66 \mathrm{~m}$. Again, there was no entrance. Around it were the pyres, pithos burials and child graves. The latter were located on the outer perimeter of the tumulus and were very small in dimension.

Tumulus Gamma ${ }^{9}$ had a perimeter of $73.24 \mathrm{~m}$ and concealed five periboloi, 34 pyres and 20 child burials in cists and pits. The periboloi were almost identical to those found at the other tumuli, with a diameter of 3-6 $\mathrm{m}$ and with their walls constructed of limestone. The pyre pits were again circular, ellipsoidal or horseshoe-shaped and built in the way described above. The child graves, mostly cists, were covered by slabs and were located on the perimeter of the tumulus. A very interesting feature of this tumulus is the existence of 14 stone constructions, scattered around the perimeter between the pyres and the child burials. Each of them consisted of a horizontal and a vertical limestone slab, meeting at right angles. The excavators believe that these constructions probably served as both funeral stelai and offering tables for ritual use. $^{10}$ Finally, small blocks of limestone and river-worn stones marked the tumulus' boundaries.

\section{BURIAL CUSTOMS}

The Thessalian EIA tumuli can be divided into two main categories: those that were built in the PG-G periods and covered one or more tholos tombs, and those that were built in the LPG-A periods and mainly contained cremation pyres. ${ }^{11}$ To the first category belong the tumuli of Agioi Theodoroi and Chyretiai, while to the second belong the tumuli of Halos. The evidence coming from the five excavated tumuli at Halos, although it does not provide us with

6 A. Delt 47 (1992), 229-32. These dimensions cannot be the original due to continuous agricultural work in the area.

7 Although such structures are described as 'tholos tombs' by the excavators, peribolos seems to be a more precise term as in none of them does a vault survive.

8 A. Delt 47 (1992), 232-4.

9 A. Delt 48 (1993), 238-40.

10 A. Delt 48 (1993), 240.

11 For the burial customs associated with the Thessalian EIA tholos tombs, see Georganas (2000, 51-2). 
a complete picture regarding the burial customs and ritual practices associated with the tumulus cemetery, can nevertheless help us to gain vital information.

As has already been mentioned, the cemetery was in use from the LPG to the Archaic period. Each tumulus concealed numerous burials, whose number seemed to depend on the needs of a particular social group (family, clan, etc). Tumulus A concealed 16 burials, Tumulus Alpha 53, Tumulus Beta 71, Tumulus Gamma 59, while the report for Tumulus E does not give the number of pyres.

The main mode of disposal used was cremation; inhumation was also represented but was confined to child burials. ${ }^{12}$ The adults were cremated in situ and the cremation pyres were either covered by a heap of stones and slabs or enclosed by a peribolos. In two cases, the cremated remains were put in pithoi. The burials in the periboloi must have been the main burials (i.e. of the head(s) of the family or clan) as all the pyres and child graves surrounded them or were located in front of them. The periboloi and the pyres constituted the main body of the tumulus while the child burials seem to have been a slightly later addition. ${ }^{13}$ This may indicate that during the earlier phases of the cemetery, children were not allowed to be buried there.

Both males and females were buried in the tumuli. ${ }^{14}$ The identification of sexes is based solely on the distribution of offerings, as no study of the bones has been undertaken so far. The men were cremated with their weapons, usually a sword, a spear and two or more knives (Wace and Thompson 1911-12, 29). The women were accompanied by their jewellery, mostly pins, rings and fibulae, but also in some cases by small knives. Pottery featured in all burials, with the same shapes occurring in all the pyres. These included two-handled open bowls, plates, trefoil-lipped oinochoai and jugs with cut-away necks (Wace and Thompson 1911-12, 21-4). The vast majority of the child burials contained no offerings.

The presence of burnt seeds such as wheat, grapes and pomegranate in some of the pyres of tumuli Alpha and Beta in conjunction with the 14 'tables of offerings' in Tumulus Gamma and the animal bones in Tumulus E, allows us to conclude that various ritual activities were performed either at the time of the burial and/or some time after it. These may have included libations and animal sacrifices followed by feasting. The presence of ashes, pottery sherds and fragments of a lopas (bronze cooking pot) on one of these tables seems to support this idea. ${ }^{15}$

\section{CREATING IDENTITIES}

The Halos pyre-cairn-tumulus combination is unique not only in Thessaly but also in other areas of the Greek world. In the neighbouring region of Macedonia, at the well-known EIA tumulus cemetery of Vergina, inhumation in pit graves prevails while cremation is extremely rare (Andronikos 1969, 164). At Chauchitsa (Casson 1919-21, 7; 1923-25, 3) and Dion (Pantermalis 1989, 46-7; 1997, 67-8) inhumation is the only mode of disposal used, as it is in the tumuli of Pogoni in Epirus. ${ }^{16}$ This has led many scholars to look for parallels outside

12 Malakasioti $(1997,192)$ in her review of the Halos tumuli mentions two cases of adult inhumations in pits. This, however, contradicts the excavation reports.

13 A. Delt 48 (1993), 240.

14 We are not sure if Tumulus E included any female burials.

15 A. Delt 48 (1993), 240.

16 A. Delt 36 (1981), 271-2; A. Delt 38 (1983), 229-30 and also Andreou and Andreou (1999, 77-90). 
the central area of Greek civilization, and especially in the Balkans, where tumuli have a very long tradition. ${ }^{17}$ Snodgrass $(1971,162)$, for example, has noticed that the tumuli of the Glasinac plateau in Bosnia contained several inhumations and cremations, each of them usually covered by a cairn. It has, therefore, been suggested that the Halos tumuli were erected by people of northern origin, who at some point settled there (Hammond 1972, 403-4).

But is it necessary to look for parallels outside the Greek world? Thessaly itself has already provided us with similar 'unusual' patterns when it comes to cemeteries, and, in fact, many scholars have pointed out the high degree of variation observed in the Thessalian burial practices (Snodgrass 1971, 154-5). The sites of Krannon and Agios Georgios, south-west of Larisa, exhibit two such cases. The first concerns the PG cemetery of Krannon, at the place known as Girlenia. ${ }^{18}$ There we have four types of grave (boulder cists, 'open burials', a peribolos and a pit grave), which, although not uncommon in the rest of Thessaly (except the 'open burials' which seem to be unique in Krannon), are never found together in any other cemetery. The second case is related to the Archaic cemetery of Agios Georgios (Tziafalias 1978, 156-82; 1994, 179-88). The excavations there revealed two large burial mounds covering a number of periboloi. The latter were ellipsoid or rectangular-shaped inside, but almost horseshoe-shaped outside. They contained cremation urns accompanied by numbers of bronze and iron offerings, mostly weapons. Of great significance is the presence of parts of two chariots or carriage wagons among the offerings. The combination of the burning of chariots along with the cremation of their owners is unique in Archaic Greece (Tziafalias 1978, 178). ${ }^{19}$ These two cases clearly reflect local customs, and I believe that we should accept them as such instead of looking for parallels in other regions. Regional variations in the various aspects of life and death are common, especially during these difficult and transitional times that are usually, though erroneously, called the 'Dark Ages'.

Strong evidence supporting a non-northern origin of the occupants of the Halos tumuli comes from the site itself. Most of the pottery retrieved from the pyres belongs to the typical EIA Thessalian repertoire, including cut-away necked jugs, trefoil-lipped oinochoai, skyphoi with high projecting handles and plates (Wace and Thompson 1911-12, 21-4). The cut-away necked jugs and the skyphoi with the high projecting handles are of great significance, as they are almost exclusively found in Thessaly and Macedonia during this period (Verdelis 1958, 41). It should also be noted that some of the pottery shows clear Attic Middle-Late Geometric influence, indicating contacts with southern Greece. In particular, Atticizing skyphoi have been found in all the pyres of Tumulus A, while kraters with Attic influence are also present (Coldstream 1968, 161-3). At the same time, we have no pottery imported from the north or any locally-made imitations of northern shapes. ${ }^{20}$ The evidence from the metal artefacts again supports a nonforeign origin. Most of the fibulae that accompanied the female cremations belong to Blinkenberg's Type VII, which is widely represented in Thessaly (Blinkenberg 1926, 128-47, esp. 133-4). The iron weapons found in the male cremations complete the picture. The swords are of the Griffzungenschwert type (generally referred to as 'Naue II'), the principal, if not the only, cut-and-thrust sword used in the eastern Mediterranean during this period (Snodgrass 1964,

17 See, for example, Snodgrass (1971, 160-3, 190), Bouzek (1997, 74-6 with references) and Harding (2000, 1003).

18 A. Delt 38 (1983), 204-8, Tziafalias and Zaouri (1999, 143-52).

19 On the contrary, wagon burials were very popular in Central Europe during the Late Bronze and Early Iron Ages (Pare 1992). Some isolated examples are also known from Cyprus (Crouwel 1987).

20 I owe this information to Mr Vladimir Stissi who studies the EIA pottery from the Halos area. 
93). This type derived from the similar bronze swords widely used in the Aegean during the Late Bronze Age. The only evidence which might indicate a probable northern origin comes from some of the spearheads found in Tumulus A. Eight out of ten fall into Snodgrass' Type Q, a type which is rare in Greece but quite common in the Balkans (Snodgrass 1964, 130). In the other three tumuli, however, most of the spearheads recovered belong to Type J, which is very common in the Greek world (Malakasioti 1997, 194; Snodgrass 1964, 123-6).

As we can see, the offerings that accompanied the occupants of the Halos tumuli are generally typical for the region and do not show any particular foreign elements. If to this we add the wide diversity of mortuary practices observed in EIA Thessaly, then we can safely conclude that the Halos tumuli were erected by local people.

Now that we have established the local character of the tumuli, we can move to the second part of our argument, that of the desire for a 'new identity'. The construction of tumuli over cremation pyres is in marked contrast with the inhumations in cist graves observed in Halos during the earlier phases of the PG period. In 1912, Wace and Thompson (1911-1912, 38) excavated a group of 11 tombs, not far from the tumulus-cemetery. Eight of them were typical cists, two were of the 'boulder' variant and the other was a round enclosure, usually described as a tholos tomb, although like the periboloi in the tumuli it did not have an entrance. All but one of the graves contained the skeletons of children. One may argue that this difference in burial rites can be explained simply on the grounds of age. Any assumption, however, that cist graves were used only for children and tumuli for adults is invalid. As we have already seen, children were also buried in the Halos tumuli, and cist cemeteries with mostly adult burials were very frequent in Thessaly (e.g. the G cist-cemetery at the sanctuary of Enodia at Pherai) (Béquignon 1937, 50-5).

So what were the reasons behind this innovative burial custom? The adoption of new mortuary practices and rituals is usually explained as either the result of foreign influence or a reflection of a new social reality (Voutsaki 1998, 44). The latter, which may have different facets including political, economic and religious, has mainly to do with the fact that mortuary practices, and especially funerals, are lively, political events at which social roles are renegotiated and re-evaluated (Parker Pearson 1999, 32). Therefore, burials can become a powerful resource in the hands of the various social groups, capable of expressing various perceived or desired 'realities' (Preston 1999, 134).

In our case, the people of Halos choose mortuary differentiation in order to create a new social reality, namely a new identity; an identity which does not necessarily have to do with a distinctive ethnic group struggling to promote its different ethnic background, but with a community trying to promote its individuality by detaching itself from both past and contemporary traditions. ${ }^{21}$ History has shown that in times of rapid social change people behave in different ways. In our case, during the eighth century BC, two main behavioural patterns can be observed. In the first, some people attempt to gain authority by forging links with distant ancestors for the purpose of legitimating territorial and socio-political claims (Hall 1997, 138-9). This is usually achieved by the establishment of 'hero' and 'tomb' cults or by the re-use of Bronze Age tholos and chamber tombs (Snodgrass 1971, 190-4; Antonaccio 1995; Morris 1988; Whitley 1995). Others, however, pay more attention to current kinship ties, attempting to reinforce the position of their community through its members' solidarity. This is

21 According to Hall $(1995,10-11)$ in order for the phenomenon to be characterized as ethnic, it should be connected with an ancestral legitimation, something that does not apply here. 
mainly achieved by the foundation of family grave-plots or the grouping of tombs and burials in some other way (Snodgrass 1971, 194-6). In this category we could include the people of Halos.

The reason for choosing that particular combination of burial rites is again not easily explained, although we should take into consideration the limited range of alternatives available to them. Tholos tombs, the other form of elaborate grave, were widely used throughout Thessaly during this period (Georganas 2000), as were the more humble cist and pit graves. The selection of tumuli, therefore, becomes the next option, as by definition they are a means of grouping burials belonging to a particular social group. In addition, they constitute an impressive landmark, visible from a great distance, and they can also be used as territorial markers expressing in a symbolic way ownership of the land (Wells 1990, 128). These factors clearly played a fundamental role in the decision behind the selection of this type of monument, as they all seem to serve well the needs of a community wishing to promote its individuality.

As the erection of a tumulus requires a relatively large amount of work and raw materials, making the whole process a venture of considerable expenditure, it is very probable that the first to use this new custom were the leading families of the community. However, it was very rapidly adopted by all members of the community, making it the only 'proper' burial practice. This is clearly reflected in the almost complete absence of any other form of burial in the area during this period. In this way, Halos became a very distinctive entity within EIA Thessaly, but without losing its Thessalian character.

In conclusion, I should stress the uniqueness of the Halos cemetery, a fact that calls for further archaeological work to be done and makes the detailed publication of the finds from the already excavated tumuli imperative.

Department of Archaeology

University of Nottingham

University Park

Nottingham NG7 2RD

\section{Acknowledgements}

I should like to thank Dr W.G. Cavanagh, Dr J. Roy and Miss C. Gallou for commenting on earlier drafts of this paper. Of course, any faults are entirely my own. I am also indebted to Mr V. Kontonatsios, president of the 'Othrys' Archaeological Society, for providing me with copies of the papers of Giannopoulos (1899) and Malakasioti (1997).

A Archaic

EIA Early Iron Age

G Geometric

LPG Late Protogeometric

PG Protogeometric

SPG SubProtogeometric 


\section{REFERENCES}

ANDReOU, E. and ANDreou, I. 1999: E Koilada tou Gormou sto Pogoni tes Epeirou, Kentro Zoes kai Anaptekses kata ten Proime Epoche tou Siderou. In E Periphereia tou Mykenaikou Kosmou. A' Diethnes Diepestemoniko Symposio Lamia, 25-29 Septemvriou 1994 (Lamia), 77-90.

ANDRONIKOS, M. 1969: Vergina I: To Nekrotapheio ton Tymvon (Athens).

ANTONACCIO, C.M. 1995: An Archaeology of Ancestors: Tomb Cult and Hero Cult in Early Greece (Lanham).

ARVANITOPOULOS, A. 1914: Anaskaphai kai Ereunai en Thessalia kai Makedonia kata ta ete 1913 kai 1914. PAE, 149-218.

BEQUIGNON, Y. 1937: Recherches archéologiques a Phères de Thessalie (Paris).

BLINKENBERG, C. 1926: Fibules grecques et orientales (Copenhagen).

BOUZEK, J. 1997: Greece, Anatolia and Europe: Cultural Interrelations During the Early Iron Age (Jonsered, SIMA 122).

CASSON, S. 1919-21: Excavations in Macedonia. BSA 24, 1-33.

CASSON, S. 1923-25: Excavations in Macedonia-II. BSA 26, 1-29.

COLDSTREAM, N. 1968: Greek Geometric Pottery (London).

CROUWEL, J.H. 1987: Chariots in Iron Age Cyprus. RDAC, 101-18.

DAKORONIA, PH. 1987: Marmara. Ta Ypomykenaika Nekrotapheia ton Tymvon (Athens).

EFSTAthiou, A., MALASIOTI, Z. and REINDERS, R. 1990: Halos Archaeological Field Survey Project: Preliminary report of the 1990 campaign. Newsletter of the Netherlands Institute at Athens 3, 31-45.

GEORGANAS, I. 2000: Early Iron Age Tholos Tombs in Thessaly (c. 1100-700 BC). Meditarch 13, 47-54.

GiAnNopoulos, N. 1899: Ekthesis Anaskaphon en Alo. Deltion tes en Almyro Philarchaiou Etaireias "Tes Othryos" 1, 31-2.

HALL, J.M. 1995: Approaches to Ethnicity in the Early Iron Age of Greece. In Spencer, N. (ed.), Time, Tradition and Society in Greek Archaeology (London), 6-17.

HALL, J.M. 1997: Ethnic Identity in Greek Antiquity (Cambridge).

HAMMOND, N.G.L. 1972: A History of Macedonia I (Oxford).

HARDING, A.F. 2000: European Societies in the Bronze Age (Cambridge).

KAlligAS, P.G. 1992: Thessalia kai Euboia kata te Proime Epoche tou Siderou. In Praktika Diethnous Synedriou Gia Ten Archaia Thessalia, Ste Mneme Tou Demetre R. Theochare (Athens), 298-307.

MALAKASIOTI, Z. 1997: Taphikoi tymvoi sten perioche Voulokalyva-Platanou Almyrou: E periptose tou agrou D. Despotopoulou. In Achaiophthiotika B'. Praktika tou B' Synedriou Almyriotikon Spoudon, 3-4 Iouniou 1995. Vol. A' (Almyros), 189-96.

MORRIS, I. 1988: Tomb Cult and the 'Greek Renaissance': the Past in the Present in the 8th century BC. Antiquity 62, 750-61.

MULLER, S. 1989: Les tumuli helladiques: Où? Quand? Comment? BCH 113, 1-42.

PANTERMALIS, D. 1989: Dion: To Nekrotapheio ton Tymvon. Archaiologia 33, 46-7.

PANTERMALIS, D. 1997: Dion: Archaiologikos Choros kai Mouseio (Athens).

PARE, C.F.E. 1992: Wagons and Wagon-Graves of the Early Iron Age in Central Europe (Oxford).

PARKER PEARSON, M. 1999: The Archaeology of Death and Burial (Gloucestershire).

PELON, O. 1976: Tholoi, Tumuli et Cercles Funéraires (Paris).

PRESTON, L. 1999: Mortuary Practices and the Negotiation of Social Identities at LM II Knossos. BSA 94, 131-43. 
SNODGRASS, A. 1964: Early Greek Armour and Weapons from the End of the Bronze Age to 600 BC (Edinburgh).

SNODGRASS, A. 1971: The Dark Age of Greece (Edinburgh).

THEOCHARIS, D. 1968: O Tymvos tou Hexalophou kai e Eisvole ton Thessalon. AAA 1, 289-95.

TZIAFAliAS, A. 1978: Anaskaphikes Ereunes ston Agio Georgio Larises. AAA 11, 156-82.

TZIAFAliAS, A. 1994: Agios Georgios Larisas. In Thessalia. Dekapende Chronia Archaiologikes Ereunas, 1975-1990. Apotelesmata kai Prooptikes (Athens), 179-88.

TZIAFAliAS, A. and ZAOURI, A. 1999: Apo te Perraivia os ten Archaia Krannona: Nekrotapheia tes Proimes Epoches tou Siderou. In E Periphereia tou Mykenaikou Kosmou. A’ Diethnes Diepestemoniko Symposio Lamia, 25-29 Septemvriou 1994 (Lamia), 143-52.

VERDELIS, N. 1958: O Protogeometrikos Rythmos tes Thessalias (Athens).

VOUTSAKI, S. 1998: Mortuary Evidence, Symbolic Meanings and Social Change: A Comparison between Messenia and the Argolid in the Mycenaean Period. In Branigan, K. (ed.), Cemetery and Society in the Aegean Bronze Age (Sheffield), 41-58.

WACE, A.J.B. and THOMPSON, M.S. 1911-12: Excavations at Halos. BSA 18, 1-29.

WELLS, B. 1990: Death at Dendra: on Mortuary Practices in a Mycenaean Community. In Hägg, R. and G.C. Nordquist (eds.), Celebrations of Death and Divinity in the Bronze Age Argolid. Proceedings of the Sixth International Symposium at the Swedish Institute at Athens, 11-13 June, 1988 (Stockholm), 12540.

WhitLey, A.J. 1995: Tomb Cult and Hero Cult: the Uses of the Past in Archaic Greece. In Spencer, N. (ed.), Time, Tradition and Society in Greek Archaeology (London), 43-63. 